13 The subject of poetry and poetic inspiration may be found in poems IX, XVII, and $\mathrm{XX}$ in The North Ship, and there is "that lifted, rough-tongued bell / (Art if you like)" from "Reasons for Attendance" in The Less Deceived.

14 Poem VI from The North Ship; a similar loneliness is described in IV, XVI, XVIII.

15 Geoffrey Thurley describes "failure" as the "great theme of all Larkin's work," in The Ironic Harvest: English Poetry in the Twentieth Century (London: Arnold, 1974), p. 147. Calvin Bedient, in gentler tones, refers to Larkin's "ancient familiarity with defeat" in his critical study, Eight Contemporary Poets (London: Oxford University Press, 1974), p. 70.

16 "No Right of Entry," Phoenix (Autumn and Winter, 1973-74), p. 107.

17 David Timms in this connection remarks: "Larkin has a fine dramatic sense, within poems and within collections." " 'Church Going' Revisited: 'The Building' and The Notion of Development in Larkin's Poetry," Phoenix (Autumn and Winter, 1973-74), p. 15.

18 From Kingsley Amis's "Against Romanticism," a manifesto poem included in New Lines.

19 Philip Larkin, in Poets of the Fifties: Anthology of New English Verse, ed. D. J. Enright (Tokyo: The Kenkyusha Press, 1955), p. 78.

\title{
Sylvia Plath and Confessional Poetry: A Reconsideration
}

When M. L. Rosenthal first used the term, confessional poetry, he had in mind a phase in Robert Lowell's career when Lowell turned to themes of sexual guilt, alcoholism, confinement in a mental hospital, and developed them in the first person in a way that intended, in Rosenthal's view, to point to the poet himself. Rosenthal was careful to limit the possibilities of the mode but he did name Sylvia Plath a confessional poet as well because, he said, she put the speaker herself at the center of her poems in such a way as to make her psychological vulnerability and shame an embodiment of her civilization. ${ }^{1}$ Rosenthal's widely accepted estimation was challenged first by Ted Hughes who pointed out that Plath uses autobiographical details in her poetry in a more emblematic way than Lowell, and more recently by Marjorie Perloff who claims that Plath's poetry lacks the realistic detail of Lowell's work. ${ }^{2}$ If Hughes and Perloff are right, and I think they are, then we should reconsider the nature of the speaker in Plath's poems, her relationship to the poet, and the extent to which the poems are confessional. 
What distinguishes Plath's poems from Lowell's is precisely the kind of person in the poem. With Lowell, according to Rosenthal, it is the literal self. Lowell himself has said that while he invented some of his autobiography, he nonetheless wants the reader to feel it is true, that he is getting the real Robert Lowell. ${ }^{3}$ The literal self in Lowell's poetry is to be sure a literary self, but fairly consistently developed as a self-deprecating, modest, comic figure with identifiable parents, summer homes, experiences at particular addresses. When he discloses under these circumstances his weaknesses, his ineptitude, his misery, his inflicting of pain on others, he is in fact revealing information that is humiliating or prejudicial to himself. In this sense, the person in the poem is making an act of confession, and, although we as readers have no power to forgive, Lowell's self-accusatory manner makes it impossible to judge. We are not outraged but chastened by such revelations. With Plath, it is otherwise. The person in her poem calls certain people father or mother but her characters lack the particularity of Commander and Mrs. Lowell. They are generalized figures not real-life people, types that Plath manipulates dramatically in order to reveal their limitations. Precisely because they are such types, the information that Plath reveals about them is necessarily prejudicial and has consequently misled some readers who react with hostility to what she has to reveal. Elizabeth Hardwick calls her lacerating and claims that Plath has the distinction of never being in her poems a nice person. ${ }^{4}$ While niceness is not a perfect standard for judging a person in a poem, Hardwick's reaction and that of many other critics who follow her reveal the particular way in which Plath's revelations are prejudicial to her. Plath's outraged speakers do not confess their misery so much as they vent it, and this attitude, unlike that of Lowell's characters, makes them susceptible to rather severe critical judgments. However, if we look at the strategy of the poems, we might arrive at a more accurate estimate of the person in them and of her relationship to the poet.

Sylvia Plath herself has said, "I think my poems immediately come out of the sensuous and emotional experiences I have, but I must say I cannot sympathize with these cries from the heart that are informed by nothing except a needle or a knife, or whatever it is. I believe that one should be able to control and manipulate experiences, even the most terrifying, like madness, being tortured, this sort of experience, and one should be able to manipulate these experiences with an informed and intelligent mind."5 The difference between Plath and Lowell is clearly outlined when we set this statement next to Lowell's account of how he came to write confessional poetry. He says that when he started writing the poems in Life Studies he had been doing a number of readings on the West Coast and found that he was simplifying his poems, breaking the meter, making impromptu 
changes as he read. He claimed that poets had become proficient in forms and needed to make a "breakthrough back into life." Life Studies may be read as that repossession of his own life, and its mode is properly confessional because both in the poems and the prose of that volume the suffering and victimizing speaker searches through his own pain in order to perceive some truth about the nature of his experience. Plath's speakers make no such search. They are anxious to contain rather than to understand their situation. When Lowell's speaker in "Skunk Hour" says, "My mind's not right," he expresses some kind of desolate self-knowledge. By contrast, Plath calls the maddened woman in "Miss Drake Proceeds to Supper," "No novice / In those elaborate rituals / Which allay the malice / Of knotted table and crooked chair." Both characters may be mad but their strategies differ. Where Lowell's character confesses his weakness, Plath's character employs all her energies in maintaining a ritualistic defense against her situation. She seems in a perverse way to act out the program of the poet whose informed and intelligent mind must manipulate its terrifying experiences. There is in fact a strange correspondence between Miss Drake's methods and those of her creator. Miss Drake is superbly sensitive, wildly inventive in objectifying her fears, and skilled at controlling them. But there is also a vast distance between Miss Drake and the poet, a distance that may be measured by the techniques of parody, caricature, hyperbole that Plath employs in characterizing her. There is something perversely comical about Miss Drake who "can see in the nick of time / How perilous needles grain the floorboards." If Miss Drake's rigid efforts are not quite ridiculed, it is fair to say that she does not engage our sympathies in the way that Lowell's speaker in "Skunk Hour" (who may also be ridiculous) does. She has been distanced from us by the poet who sees her as a grotesque reflection of herself, employing the manipulative strategies of the uninformed mind against an undefined terror, channeling what might have been creative energy into pointless rituals.

"Miss Drake Proceeds to Supper" is an early poem but it reveals the way in which Plath controlled her own terrifying experiences in her poetry. She did so by creating characters and later speakers who demonstrate the way in which the embattled mind operates. Far from speaking for the poet, they stage crazy performances which are parodic versions of the imaginative act. Through them, Plath shows how terror may grip the mind and render it rigid. Through her speaker's projective fantasies, she projects her own understanding of hysterical control and the darker knowledge of its perilous subversion of the imagination. While Miss Drake's elaborate rituals are designed to hold off her fears, the poet who created her is handling in the act of the poem, however indirectly, her own frightening knowledge of madness. What for the mad woman is a means of 
avoiding experience becomes for the poet a means of controlling it. The poems, unlike the speakers in them, reveal Plath's terrifying self-knowledge.

In her poems, Plath is not concerned with the nature of her experience, rather she is engaged in demonstrating the way in which the mind deals with extreme circumstances or circumstances to which it responds with excessive sensitivity. The typical strategy of her speakers is to heighten or exaggerate ordinary experience and at the same time to intensify the mind's manipulative skills so that fathers become Fascists and the mind that must deal with the image it has conjured up becomes rigidly ritualistic. In her early poems, Plath stands outside and judges her characters, drawing caricatures not only of madness but of its counterpart, hysterical sanity. As she continued to write however, she began to let the characters speak for themselves in caricature, parody, and hyperbole which they use not as vehicles of judgment but as inevitable methods of their performances. When the mind that must deal with terror stiffens and rigidifies, parody will become its natural means of expression.

Between "Miss Drake Proceeds to Supper" and her late poems, however, Plath explored another way in which the mind responds to its terrors. In what has been called her middle period, Plath became interested in a kind of character who had been exhausted by her fears and could not control experience. For example, the insomniac of "Zoo Keeper's Wife" lies awake at night thinking over her grievances and the particular horrors of her husband's zoo full of "wolf-headed fruit bats" and the "bird-eating spider." Her response to her husband is as hyperbolic as the hysterical spinster's disdain for love's slovenliness in an early Plath poem but she has no rituals with which to deal with it nor barricades to hide behind. Rather, she says, "I can't get it out of my mind." All she can do is "flog apes owls bears sheep / Over their iron stile" and still she can't sleep. Again, in "Insomniac," the mind cannot handle memories that "jostle each other for face-room like obsolete film stars." The speaker's "head is a little interior of grey mirrors. / Each gesture flees immediately down an alley / Of diminishing perspectives, and its significance / Drains like water out the hole at the far end." It is in these poems and others like them of this period that Plath's speakers sound most like Lowell's in his more exhausted and despairing moods yet even here Plath focuses on the function or nonfunction of the mind rather than on the meaning of the experience.

As Plath turned into her later period in a poem such as "Tulips" the speaker of her poem seems to welcome the loss of control that had harried the insomniacs. As she goes into the hospital in this poem, she claims to be learning peacefulness, and she hands herself over to the hospital attendants to be propped up and tended to. The nurses bring her numbness in "bright needles," and, as she succumbs to the anethesia, she claims that she only 
wanted to be utterly empty. However, she does not rest in that attitude very long before she comes out of the operating room and its anesthetized state and begins reluctantly to confront her pain. Her first response is to complain that the tulips hurt her, watch her, that they eat up her oxygen. But, when the speaker claims a correspondence between the tulips' redness and her own wound, her manipulative mind begins to function again, first in negative ways, tormenting itself by objectifying its pain. Then, in a brief but alarming reversal, the speaker associates the tulips not only with the pain but with the heart so that the outside threat and power are not only overcome but subsumed. Because the speaker here has so exaggerated her own emptiness and the tulips' violence and vitality, she must then accept in herself the attributes she has cast onto the tulips which now return to her. The heart blooms. Here, for once, the manipulative mind works its own cure. If the supersensitive mind can turn tulips into explosions, it can also reverse the process and turn dangerous animals into blooming hearts. What it cannot do, despite the speaker's claim, is accept utter emptiness. It cannot refuse to be excited by the flowers that it does not want.

"Tulips" is an unusual poem in Plath's work not because it demonstrates how the mind may generate hyperboles to torture itself (which is a common strategy of Plath's poems) but because it shows how this generative faculty may have a positive as well as a negative function. "Tulips" is not a cheerful poem, but it does move from cold to warmth, from numbness to love, from empty whiteness to vivid redness, a process manipulated by the associative imagination. The speaker herself seems surprised by her own gifts and ends the poem on a tentative note, moving toward the faraway country of health. Despite this possibly hopeful ending, however, the body of the poem demonstrates the way in which the mind may intensify its pain by objectifying it.

What takes place in "Tulips" in a private meditation (and perhaps the privacy accounts for the mind's pliancy) is given a much more ferocious treatment in the public performances of Plath's late poems. It is in fact the sense of being on public display that calls forth the rage of the speakers in these late poems. Forced to perform, they develop elaborate rituals. Their manipulative powers become a curse not a cure. In "The Tour," the speaker, caught "in slippers and housedress with no lipstick," greets with mock hospitality her maiden aunt who wants "to be shown about": "Do step into the hall," "Yes, yes, this is my address. / Not a patch on your place, I guess." Instead of refusing to become a victim of the aunt's meddlesome curiosity, the speaker readily assents to it. After apologizing for the mess, she leads her aunt right into it, showing her the frost-box that bites, the furnace that exploded, the sink that ate "seven maids and a 
plumber." With mock concern, she warns the aunt, "O I shouldn't put my finger in that," "O I shouldn't dip my hankie in, it hurts!" "I am bitter? I'm averse?" she asks, dropping for a second her polite mask but resuming it immediately in her refrain, "Toddle on home to tea now." The speaker manipulates the aunt's curiosity, turning it back on itself by maintaining a tone of insistent courtesy and forced intimacy that is designed to jeeringly protect the aunt from the brazen exhibition of the open house of horrors. She appears to contrast her own dreary domestic appliances to her aunt's exotic possessions (the gecko she wears as costume jewelry, her Javanese geese and monkey trees); but actually her machines are "wild," she says, and in a different way unlike her aunt's tamed decorations. However, when she calls herself "creepy-creepy," she seems to have assumed her aunt's gecko-like qualities. The staginess of this speaker, her insistent rhyming, exclamatory sentences, italicized words, all provide not only a grotesque reflection of the aunt's alarm, but also suggest a kind of hysterical control. The speaker's ability to manipulate the aunt is matched by a more sinister ability to manipulate her own horrors, to locate them in furnace and stove, and there to give them a separate identity. Her mind, like Miss Drake's, is extremely skilled at objectifying her fears. The poet who felt that the intelligent mind must manipulate its most terrifying experiences also knew that the deranged mind could operate in such a way as to hold off its terror, separate itself from the agony it suffered, and the speaker here exemplifies that process. When at the end she warns the aunt not to trip over the nurse-midwife who "can bring the dead to life," she points to the source of her misery, the creative principle that has itself assumed an objective identity and become part of the mess. The midwife, like a poet, delivers life with "wiggly fingers," and she has in fact been very active in endowing dead household appliances with a lively if destructive energy; but now she too has been cast out.

In this speaker who can not only caricature her aunt with the "specs" and "flat hat" but also her own creepiness as well as her "awfully nice" creative faculties, Plath presents a damning portrait of the too inventive mind that exults in self-laceration. It is not quite accurate to say that this speaker is unaware of her own strategies because she is supremely selfconscious; but she is trapped by them. Where others have been devoured or repelled, she lives on, neither despairing nor shocked but charged with a hysterical energy that she deploys finally against herself. Her nurse-midwife is eyeless. She too can only see herself now as others see her. Her ability to manipulate her own suffering is a subversion of the poet's creative powers; it becomes a means of holding off rather than exploring her situation.

A quite different manipulator is the speaker in "The Applicant" who 
appears to be a comic figure, reveling in her machinations. Unlike the woman in "The Tour," she seems to speak for others not for herself. She starts out with the characteristic question of the convention-loving woman, "First, are you our sort of person?" What interests her, she reveals, is not what we might expect from someone who would ask that question, the social qualities of her marriage applicant, but rather her physical parts. "Our sort of person" has no glass eyes, false teeth, rubber breasts, stitches to show something's missing. Once having assured herself on that score, she presents her applicant's hand in marriage, promising not only the traditional services that it will "bring teacups and roll away headaches" but that at the end it will even "dissolve of sorrow." Then, as if this "guaranteed" emotion might be too much for the man, she confides, "We make new stock from the salt." Such economy, such efficiency, this marriage broker seems to cluck. The woman "willing" "to do whatever you tell it" can be easily recycled. Next the speaker turns to the man who like the woman is "stark naked." Instead of putting him through the same examination of parts, she quickly offers him a wedding suit, "Black and stiff," that he can reuse as a funeral shroud. She adopts the familiar tone of the tailor ("How about this suit-" "Believe me, they'll bury you in it.") that shades into that of the mortician. Suddenly the suit, the girl, the deadly convention of marriage are all one, like a tomb, equally "waterproof, shatterproof, proof / Against fire and bombs through the roof." The subversive excess of her promises here is hastily passed over as her sales pitch continues: "Now your head, excuse me, is empty. / I have the ticket for that. / Come here, sweetie, out of the closet." What she presents is "A living doll" whose value will increase with each anniversary, paper at first but silver in 25 years and gold at 50 years.

It might be argued that "The Applicant" does not properly belong to those poems in which Plath exposes the mind's manipulation of terrifying experiences. After all, marriage-and especially the marriage contracted here-is a conventional arrangement which should not affect the fears or passions or emotions of either the man or the woman. In addition, the speaker here appears safely removed from the situation she directs. These facts, however, do not explain the tone of the poem which comes through in the insistent refrain, "Will you marry it?" This speaker who has "the ticket" for everything seems, despite her all-knowing and consoling comic pose, very anxious to have her question answered. Again, as in the other poems we have discussed, the nature of the speaker in "The Applicant" deserves more attention than it has received. What she says is obvious enough but why does she say it? I have called her a woman although her sex is nowhere identified partly because of her language (she calls the woman "sweetie" and the man "My boy") and partly because of her claim 
that her applicant can sew, cook and "talk, talk, talk" (no man, I believe would have considered that last feature a selling point) but chiefly because she seems to be extremely concerned for the successful outcome of her applicant. She is like the applicant herself willing to make any claim and to accede to any demands in order to strike a bargain. Hers is a pose of course, but it is the pose of the compliant woman. Like the patient in "Tulips" who accepts the gift of flowers that torment her and the niece in "The Tour" who responds to her aunt's detested visit, the speaker here insists on participating in a situation the demands of which she finds abhorrent. Her only recourse for dealing with it is a mode at which she is particularly skilled, burlesque. Yet behind the scorn and the scoffing is another feeling, something like hysteria, that expresses itself in her repeated question. She seems trapped by the sexual stereotypes she parodies. The ventriloquism of this poem hides the fact that this is an internal debate. The sexual fear that has driven the "sweetie" into the closet and the boy to his last resort also propels the manipulations of this shrewd if too agreeable woman. Here again is the controlling mind using its powers to compartmentalize rather than explore its situation.

"The Applicant" has been given serious consideration as Plath's statement on marriage yet it does not point to the poet herself in the same way that, for example, Robert Lowell's "Man and Wife" does. Its characters are unparticularized and unconnected to any specific event in Plath's experience. Its sexual stereotypes (the girl willing to do anything in order to be married and the boy only willing to marry if he can be convinced that he will get a worthwhile product) are manipulated by a speaker whose tension-filled control reveals not only their power over her but the terror that informs them. This speaker can manage, but she cannot escape her situation.

The relationship between poet and speaker in two other late poems, "Lady Lazarus" and "Daddy," is somewhat more complicated because these poems do call upon specific incidents in Plath's biography, her suicide attempts and her father's death. Yet to associate the poet with the speaker directly, as many critics have done, does not account for the fact that Plath employs here as before the techniques of caricature, hyperbole, and parody that serve both to distance the speaker from the poet and at the same time to project onto the speaker a subversive variety of the poet's own strategies. In "Lady Lazarus," the nature of the speaker is peculiar and defies our ordinary notions of someone prone to attempt suicide. Suicide is not a joyous act, and yet there is something of triumph in the speaker's assertion that she has done it again. The person recovering from a suicide attempt, as this speaker says she is, cannot possibly be so confident at the very moment of her recovery that her sour breath will vanish 
in a day and that she will soon be a smiling woman. Nor could she have the presence of mind to characterize those who surround her as a "peanutcrunching crowd" and her rescuers as enemies. And finally it seems psychologically impossible for the suicide victim to have the energy to rise at all against other people, much less to threaten to "eat men like air." The person who speaks here does so not to explore her situation but to control it. She is first of all a performer, and, although she adopts many different roles, she is chiefly remarkable for her control not only of herself but of the effects she wishes to work on those who surround her. She speaks of herself in hyperboles, calling herself a "walking miracle," boasting that she has "nine times to die," exclaiming that dying is an art she does "exceptionally well," asserting that "the theatrical / Comeback in broad day" knocks her out. Her treatment of suicide in such buoyant terms amounts to a parody of her own act. When she compares her suicide to the victimization of the Jews and later on when she claims there is a charge for a piece of her hair or clothes and thus compares her rescued self to the crucified Christ or martyred saint, she is engaging in self-parody. She employs these techniques partly to defy the crowd with its "brute / Amused shout: / 'A miracle!"” and partly to taunt her rescuers, "Herr Doktor" "Herr Enemy," who regard her as their "opus." She is neither a miracle nor an opus, and she fends off those who would regard her in this way. But the techniques have another function as well; they display the extent to which she can objectify herself, ritualize her fears, manipulate her own terror. Her extreme control in fact is intimately entwined with her suicidal tendencies. The suicide is her own victim, can control her own fate. If she is not to succumb to this desire, she must engage in the elaborate ritual which goes on all the time in the mind of the would-be suicide by which she allays her persistent wish to destroy herself. Her act is the only means of dealing with a situation she cannot face. Her control is not sane but hysterical. When the speaker assures the crowd that she is "the same, identical woman" after her rescue, she is in fact telling them her inmost fear that she could and probably will do it again. What the crowd takes for a return to health, the speaker sees as a return to the perilous conditions that have driven her three times to suicide. By making a spectacle out of herself and by locating the victimizer outside herself in the doctor and the crowd, she is casting out her terrors so that she can control them. When she says at the end that she will rise and eat men like air, she is projecting (and again perhaps she is only boasting) her destruction outward. That last stanza of defiance is in fact an effort of the mind to triumph over terror, to rise and not to succumb to its own victimization.

The speaker's tone is hysterical, triumphant, defiant. Only once does 
she drop this tone to admit the despair that underlies it when she says, "What a trash / To annihilate each decade." Otherwise she maintains her rigid self-control in accents that range from frenzied gaiety to spiteful threats. Although her situation is much more extreme than those social occasions of "Tulips," "The Tour," "The Applicant," it is like them not of her own making. She has been rescued when she wanted to die. Her response is perverse. She does not welcome her rescuers, nor does she examine the condition that forced her death wish; instead she accepts her fate and presents herself as in complete control. The effort of her act which comes through in her tone is intense yet necessary because without it she would have to face the fact that she is not in control. Her performance is a defense against utter desolation. Here again is the mind manipulating its own terrors. Plath was no stranger to this method, as we have said before, but while she works here with a parallel between hysterical control and creative control she presents the first as a mad reflection of the second. The speaker like Miss Drake is "No novice / In those elaborate rituals" that allay her terror yet her tremendous energies are so absorbed in maintaining them that she has no reserve with which to understand why she performs as she does. When she sees herself as a victimized Jew or Christ, she may be engaging in self-parody but the extremity of her circumstances does not allow her to realize it. The poet behind the poem is not caricaturing Lady Lazarus as she had Miss Drake; she is rather allowing Lady Lazarus to caricature herself and thus demonstrating the way in which the mind turns ritualistic against horror. Despite the fact that "Lady Lazarus" draws on Plath's own suicide attempt, the poem tells us little more than a newspaper account of the actual event. It is not a personal confession. What it does reveal is Plath's understanding of the way the suicidal person thinks.

"Daddy" is an even more complicated treatment of the same process. The poem opens with the daughter's assertion that "You do not do, you do not do." But if Daddy will not do, neither will he not not do, and we find this speaker in the characteristic Plath trap, forcing herself to deal with a situation she finds unacceptable. "Daddy" is not so much an account of a true-life situation as a demonstration of the mind confronting its own suffering and trying to control that by which it feels controlled. The simplistic, insistent rhythm is one form of control, the obsessive rhyming and repeated short phrases are others, means by which she attempts to charm and hold off the evil spirits. But the speaker is even more crafty than this technical expertise demonstrates. She is skilled at image-making like a poet and she can manipulate her images with extreme facility. The images themselves are important for what they tell us of her sense of being victimized and victimizer but more significant than the actual image is the swift ease 
with which she can turn it to various uses. For example, she starts out imagining herself as a prisoner living like a foot in the black shoe of her father. Then she casts her father in her own role and he becomes "one grey toe / Big as a Frisco seal" and then quickly she is looking for his foot, his root. Next he reverts to his original boot identity, and she is the one with "The boot in the face." And immediately he returns with "A cleft in your chin instead of your foot." At the end, she sees the villagers stamping on him. Thus she moves from booted to booter as her father reverses the direction. The mind that works in this way is neither logical nor psychologically penetrating; it is simply extremely adept at juggling images. In fact, the speaker is caught in her own strategies. She can control her terrors by forcing them into images, but she seems to have no understanding of the confusion her wild image-making betrays. When she identifies herself as a foot, she suggests that she is trapped, but when she calls her father a foot the associations break down. In the same way, when she caricatures her father as a Fascist and herself as a Jew, she develops associations of torture which are not exactly reversed when she reverses the identification and calls herself the killer of her vampire-father. The speaker here can categorize and manipulate her feelings in name-calling, in rituals, in images, but these are only techniques, and her frenzied use of them suggests that they are methods she employs in the absence of any other. When she says, "Daddy, I have had to kill you," she seems to realize the necessity of the exorcism and to understand the ritual she performs, but the frantic pitch of the language and the swift switches of images do not confirm any self-understanding. The pace of the poem reveals its speaker as one driven by a hysterical need for complete control, a need that stems from the fear that without such control she will be destroyed. Her simple, incantatory monologue is the perfect vehicle of expression for the orderly disordered mind.

In talking to A. Alvarez, Plath called these poems "light verse." "Daddy" does not seem to fall easily into that category despite its nonsense rhymes and rhythms, its quickly flicking images. It is neither decorous nor playful. On the other hand, given its subject, neither is it ponderous or solemn. Above all it offers no insight into the speaker, no mitigating evidence, no justification. Plath's classification is clear perhaps only if we consider her speaker a parodic version of the poet. The speaker manipulates her terror in singsong language and thus delivers herself in "light verse" that employs its craft in holding off its subject. For all the frankness of this poem, the name-calling and blaming, the dark feeling that pervades it is undefined, held back rather than revealed by the technique. The poet who has created this speaker knows the speaker's strategies because they 
are a perverted version of her own, and that is the distinction between the speaker's "light verse" and the poet's serious poem.

From her earliest madwomen and hysterical virgins to the late suicides and father-killers, Plath portrays characters whose stagey performances are subversions of the creative act. Absorbed in their rituals, they confess nothing. They are not anxious to make a breakthrough back into life. In fact, their energies are engaged in erecting a barricade against self-revelation. Plath's fascination with this parodic image of the creative artist stems from a deep knowledge of the machinations of the mind. If she reveals herself in these poems, she does so in the grotesque mirror of parody. If these poems come out of her own emotional experiences, as she said they did, they are not uninformed cries from the heart. Rather, she chose to deal with her experience by creating characters who could not deal with theirs and through their rituals demonstrate their failure. These poems, like the speakers in them, are superbly controlled; but the poet behind the poem uses her immense technical control to manipulate the tone, the rhythm, the rhyme, the pace of the speakers' language in order to reveal truths about the speakers that their obsessive assertions deny.

\section{NOTES}

1 M. L. Rosenthal, The New Poets (New York: Oxford University Press, 1967), pp. 25-89.

2 Ted Hughes, "Notes on the Chronological Order of Sylvia Plath's Poems," Tri-Quarterly, 7 (Fall, 1966), 81-82, and Marjorie Perloff, The Poetic Art of Robert Lowell (Ithaca: Cornell University Press, 1973), pp. 181-183.

3 Frederick Seidel, "An Interview with Robert Lowell," in Robert Lowell: A Portrait of the Artist in His Time, ed. Michael London and Robert Boyers (New York: David Lewis, 1970), p. 272.

4 Elizabeth Hardwick, rev. of The Bell Jar and Crossing the Water, The New York Review of Books, 17 (August 12, 1971), pp. 3-6.

5 Sylvia Plath in The Poet Speaks, ed. Peter Orr (London: Routledge \& Kegan Paul, 1966), p. 169. 